\title{
MENINGKATKAN PRODUKTIVITAS SAPI BALI MELALUI PELAYANAN KESEHATAN DI DESA BELOK/ SIDAN KABUPATEN BADUNG
}

\author{
N.L.E. Setiasih ${ }^{1}$, I.K. Suatha ${ }^{2}$, P. Suastika ${ }^{1}$, D.N.D.I. Laksmi ${ }^{3}$
}

\begin{abstract}
ABSTRAK
Penyakit menjadi salah satu kendala bagi peternak sapi bali untuk meningkatkan produktivitas ternak. Pelayanan kesehatan menjadi salah satu usaha yang dapat dilakukan untuk mengurangi kerugian akibat penyakit. Tujuan dilakukan pengabdian ini adalah meningkatkan produktivitas sapi bali melalui pelayanan kesehatan di Desa Belok/Sidan Kabupaten Badung. Pelayanan kesehatan yang diberikan meliputi spraying, pemberian obat cacing, vitamin dan antibiotik di dusun Sekarmukti dan Belok, Desa Belok/Sidan. Jumlah peternak yang berhasil disasar sebanyak 64 orang dengan jumlah sapi sebanyak 190 ekor. Pelayanan kesehatan ini berhasil dilakukan dan mendapat respon sangat baik dari peternak di Desa Belok/Sidan. Masyarakat petani peternak menginginkan kegiatan tersebut dilakukan secara rutin setiap tahunnya.
\end{abstract}

Kata kunci : Sapi bali; pelayanan kesehatan, spraying; obat cacing, vitamin

\begin{abstract}
Disease became one of the obstacles for bali cattle breeders to improve livestock productivity. Health services become one of the efforts that can be done to reduce losses due to disease. The aim of this dedicated service to increase the productivity of bali cattle through health services in the Village of Belok / Sidan Badung regency. Health services provided include spraying, administering worm medicines, vitamins and antibiotics in the hamlets of Sekarmukti and Belok, the Village of Belok / Sidan. The number of farmers who successfully targeted as many as 64 people with a total of 189 head of Bali cattle. The health service was successful and obtained very good response from farmers in the village of Belok / Sidan. Community livestock farmers want these activities done routinely every year.
\end{abstract}

Keywords: Bali cattle; health service, spraying, worm drug, vitamin

\footnotetext{
${ }^{1}$ Lab Histologi, Fakultas Kedokteran Hewan, Universitas Udayana, Email: ekasetiasih@unud.ac.id

${ }^{2}$ Lab Anatomi, Fakultas Kedokteran Hewan, Universitas Udayana

${ }^{3}$ Lab Reproduksi, Fakultas Kedokteran Hewan, Universitas Udayana
}

\section{PENDAHULUAN}


Desa Belok/Sidan merupakan salah satu desa di Kecamatan Petang, Kabupaten Badung dengan luas wilayah 3.266 Ha, dengan batas wilayah: utara Desa Tambakan dan Catur, selatan Desa Petang, barat Desa Pelaga dan Sulangai, dan timur Desa Mengani dan Buahan Kaja. Kondisi geografis desa tersebut terletak pada ketinggian 800-1.200 m dari permukaan laut, dengan suhu udara rata-rata $27^{\circ} \mathrm{C}$.

Dari data monograf Desa Belok/Sidan dari bulan Juli s/d Desember 2016 tercatat bahwa Desa Belok/Sidan memiliki jumlah penduduk 5.221 orang (1.389 KK) dimana sebagian besar yaitu sebanyak 2.654 orang bermata pencaharian sebagai petani. Jumlah populasi ternak didesa tersebut adalah sapi 3.670 ekor, ayam buras 3.689 ekor, ayam ras 3.000 ekor, itik 200 ekor, kambing 26 ekor, domba 2 ekor, dan babi 1.850 ekor.

Sapi bali diketahui telah tersebar hampir di seluruh provinsi di Indonesia dan berkembang cukup pesat di banyak daerah karena memiliki banyak keunggulan (Guntoro, 2002), memiliki penampilan menarik dan relatif kompak sehingga menarik perhatian banyak pihak, baik dalam maupun luar negeri (Bandini, 2004)

Petani peternak di Desa Belok/Sidan memelihara sapi sebagai mata pencaharian utama di bidang peternakan. Selama pemeliharaannya peternak kadang menemukan kendala, salah satunya sapi peliharaannya terserang penyakit bahkan diikuti dengan kematian, sehingga sangat merugikan bagi petani peternak di Desa tersebut.

Pengembangan peternakan sapi bali di desa Belok/Sidan masih banyak mengalami hambatan baik itu masalah kesehatan maupun pengetahuan tentang beternak sapi yang baik, sehingga produksinya masih tergolong rendah. Dari komunikasi dengan salah satu kelompok ternak SIMANTRI mengatakan bahwa terjadi beberapa kasus kelahiran premature yang belum diketahui penyebabnya, dan diare pada anak sapi. Kasus lainnya adalah diare dan banyaknya lalat, hal ini mungkin karena sapi dipelihara didaerah sekitar perkebunan yang menggunakan pupuk kandang dari kotoran ayam. Kondisi ini menjadi salah satu masalah yang mengganggu produktivitas ternak sapi yang dipelihara di desa tersebut sehingga menimbulkan kerugian ekonomi yang cukup besar.

Indonesia merupakan salah satu negara beriklim tropis, dimana keadaan cuaca yang panas, sangat kering atau sangat lembab. Kondisi geografis seperti ini mempengaruhi status kesehatan ternak. Penyakit pada ternak sapi bali beragam bisa berupa penyakit virus, bakteri, parasit ataupun penyakit yang berhubungan dengan nutrisi.

Kelahiran premature pada anak sapi merupakan salah satu gangguan reproduksi. Gangguan reproduksi pada sapi potong dapat diakibatkan oleh berbagai faktor, baik infesius maupun noninfeksius. Khusus untuk gangguan reproduksi yang diakibatkan oleh agen infeksius atau penyakit menular dapat mengakibatkan abortus, pyometra, endometritis, kematian embrio, kemajiran, plasenta tertahan, maupun kerusakan syaraf pusat dari fetus (Adjid, 2014).

Penyakit diare dapat menyebabkan kematian pada anak sapi. Diare pada pedet bisa disebabkan oleh faktor infeksius dan non infeksius. Malik et al (2012) menyatakan bahwa diare menyebabkan tingginya tingkat morbiditas dan mortalitas pedet, terutama pada minggu pertama setelah lahir. Tingginya kerugian ekonomi tidak hanya karena kematian pedet, tetapi akibat biaya yang tinggi untuk pengobatan dan kerugian akibat gangguan pertumbuhan pedet. Diare non infeksius biasanya disebabkan oleh perubahan yang mendadak dari program pemberian pakan. Diare sering terjadi pada saat peralihan, ketika pedet yang semula hanya mengkonsumsi susu sebagai satu satunya sumber nutrisi, mulai makan serat kasar atau hijauan sebagai suplemen. Meskipun tidak berbahaya 
dan tidak sampai menyebabkan kematian, diare non-infeksi ini dapat dengan cepat melemahkan tubuh yang pada gilirannya dapat menyebabkan pedet rentan terkena diare infeksi atau penyakit lain yang lebih parah.

Diare infeksius, kemungkinan disebabkan oleh infeksi bakteri, virus dan protozoa. Hal ini sesuai dengan pernyataan Margerison dan Downey (2005) menyatakan problem infeksius biasanya terjadi pada tiga hari pertama kelahiran pedet berupa infeksi bakteri (E. coli, Salmonella, dan Clostrdium) sedangkan pada umur selanjutnya disebabkan oleh virus (Rotavirus dan Coronavirus), serta protozoa,yaitu Cryptosporidium spp. (Nagwa et al., 2013). Gejala klinis yang terlihat pada pedet penderita diare adalah feses encer, warna tidak normal, antara putih sampai kuning kehijauan, lemas, mata cekung. Penderita mengalami penurunan berat badan secara cepat, dan dehidrasi. Margerison dan Downey (2005), menyatakan bahwa virus Rotavirus dan Coronavirus menyebabkan kerusakan villi-villi usus, sehingga menyebabkan hilangnya kemampuan digesti dan absorbsi, yang berakibat terjadi diare dan dehidrasi pada pedet penderita.

Kematian umumnya disebabkan oleh Coliform, Clostridium perfringens, dan Salmonellosis (Williamson 2003; Supar et al., 1989). E. coli adalah kuman yang paling umum diisolasi (Aldridge et al., 1993). Priadi dan Natalia (2005) menyatakan bahwa kematian pedet tanpa disertai gejala diare di beberapa daerah di Indonesia karena enterotoksemia akibat toksin alfa dan beta $\mathrm{Cl}$. perfringens. Kuman Bacillus spp., E. Coli dan $\mathrm{Cl}$. perfringens merupakan kuman yang umum didapatkan pada faeces anak sapi.

Dengan melihat permasalahan tersebut, maka dipandang perlu untuk melaksanakan pelayanan kesehatan ternak sapi agar bisa menekan penyebaran penyakit antar kawanan ternak atau dalam satu kawanan ternak. disamping itu pengetahuan peternak dapat meningkat dan pada akhirnya dapat diterapkan langsung dilapangan, sehingga nantinya peternakan mereka dapat menghasilkan sapi yang berkualitas dan menurunkan angka kematian sapi yang secara langsung akan meningkatkan pendapatan keluarga peternak tersebut.

\section{METODE PEMECAHAN MASALAH}

Metode pemecahan masalah kesehatan ternak sapi bali di Desa Belok/Sidan, Kabupaten Badung dilakukan dengan beberapa cara, meliputi: (1) Pelayanan kesehatan ternak dengan melakukan spraying, pemberian obat cacing dan vitamin, serta pemberian antibiotik terhadap ternak sapi yang ditemukan sakit. (2) Penyuluhan tentang petunjuk dan tata cara pemeliharaan kesehatan ternak sapi serta menganjurkan pada masyarakat secara rutin mengikuti program vaksinasi yang diadakan oleh pemerintah.

\section{HASIL DAN PEMBAHASAN}

Pelaksanaan kegiatan pengabdian di Desa Belok/Sidan dilakukan di dua dusun yaitu Sekarmukti dan Belok. Kegiatan selain dilakukan pada peternak perorangan juga dilakukan terhadap kelompok ternak. Penyuluhan dan pelayanan kesehatan ternak sapi bali dilakukan kepada anggota kelompok simantri Mekar Sari dan peternak sapi disekitar kelompok simantri di Banjar Sekarmukti. Pelayanan kesehatan juga dilakukkan di wilayah lain dari Desa Belok/Sidan. Selain Banjar Sekarmukti, Banjar Belok juga mendapat pelayanan kesehatan dengan mengunjungi kandangkandang peternak. Jumlah peternak yang dapat dilayani sebanyak 65 orang, dengan rincian 24 orang pada kelompok ternak Mekar Sari dusun Sekarmukti dan 41 orang merupakan peternak 
mandiri dari banjar Sekarmukti dan Belok. Jumlah ternak sapi bali yang dapat dilayani di kelompok Ternak Sekar Sari ditunjukkan pada Tabel 3.1.

Tabel 3.1 Nama Peternak, Jumlah Ternak, dan Tindakan Pelayanan Kesehatan Ternak Sapi yang Diberikan di Desa Belok/Sidan

\begin{tabular}{|c|c|c|c|}
\hline No & Nama Peternak & $\begin{array}{l}\text { Jumlah } \\
\text { Ternak Sapi }\end{array}$ & Tindakan Pelayanan Kesehatan \\
\hline 1. & Nym. Selamet & 4 & spraying, obat cacing, vitamin \\
\hline 2. & I Wyn. Darsa & 5 & spraying, obat cacing, vitamin, antibiotik ( 1 ekor) \\
\hline 3 . & Wyn. Subur & 4 & spraying, obat cacing, vitamin \\
\hline 4. & Nym Nuka & 4 & spraying, obat cacing, vitamin \\
\hline 5. & Nym. Indi & 5 & spraying, obat cacing, vitamin \\
\hline 6. & Wyn. Susila & 6 & spraying, obat cacing, vitamin \\
\hline 7. & Nym. Kartu & 3 & spraying, obat cacing, vitamin \\
\hline 8. & Nym. Jaya & 3 & spraying, obat cacing, vitamin, antibiotik ( 1 ekor) \\
\hline 9. & Kt. Janten & 4 & spraying, obat cacing, vitamin \\
\hline 10. & Md. Nuka & 5 & spraying, obat cacing, vitamin \\
\hline 11. & Md. Rajeg & 8 & spraying, obat cacing, vitamin, antibiotik ( 2 ekor) \\
\hline 12. & I Md. Senti & 4 & spraying, obat cacing, vitamin \\
\hline 13. & I Wyn. Rata & 2 & spraying, obat cacing, vitamin \\
\hline 14. & I Md. Radia & 3 & spraying, obat cacing, vitamin \\
\hline 15. & I Nym. Jaya & 3 & spraying, obat cacing, vitamin \\
\hline 16. & I Wyn. Subur & 1 & spraying, vitamin \\
\hline 17. & I Wyn. Sumata & 2 & spraying, obat cacing, vitamin \\
\hline 18. & Md. Puja & 3 & spraying, obat cacing, vitamin \\
\hline 19. & I Md Suwita & 4 & spraying, obat cacing, vitamin, 1 ekor di PKB \\
\hline 20. & I Wyn. Astina & 2 & spraying, obat cacing, vitamin \\
\hline 21. & I Nym. Jasa & 3 & spraying, obat cacing, vitamin \\
\hline 22. & I Wyn. Jarsa & 4 & spraying, obat cacing, vitamin \\
\hline 23. & I Wayan Gata & 4 & spraying, obat cacing, vitamin \\
\hline \multirow[t]{2}{*}{24.} & I Md. Sumbrig & 2 & spraying, obat cacing, vitamin \\
\hline & Jumlah & & 88 ekor sapi \\
\hline
\end{tabular}

Penyuluhan dilakukan atas permintaan peternak, karena selain dalam rangka evaluasi simantri tingkat Provinsi Bali, juga beberapa peternak melaporkan kasus partus secara premature, prolapsus, kegagalan kebuntingan, dan diare. Penyuluhan diberikan untuk mencegah dan mengurangi kejadian tersebut (Gambar 3.1). Anggota tim pelaksana pengabdian memberikan penyuluhan tentang beberapa penyebab, cara mencegah dan menanggulangi beberapa kendala kesehatan ternak sapi bali di wilayah tersebut.
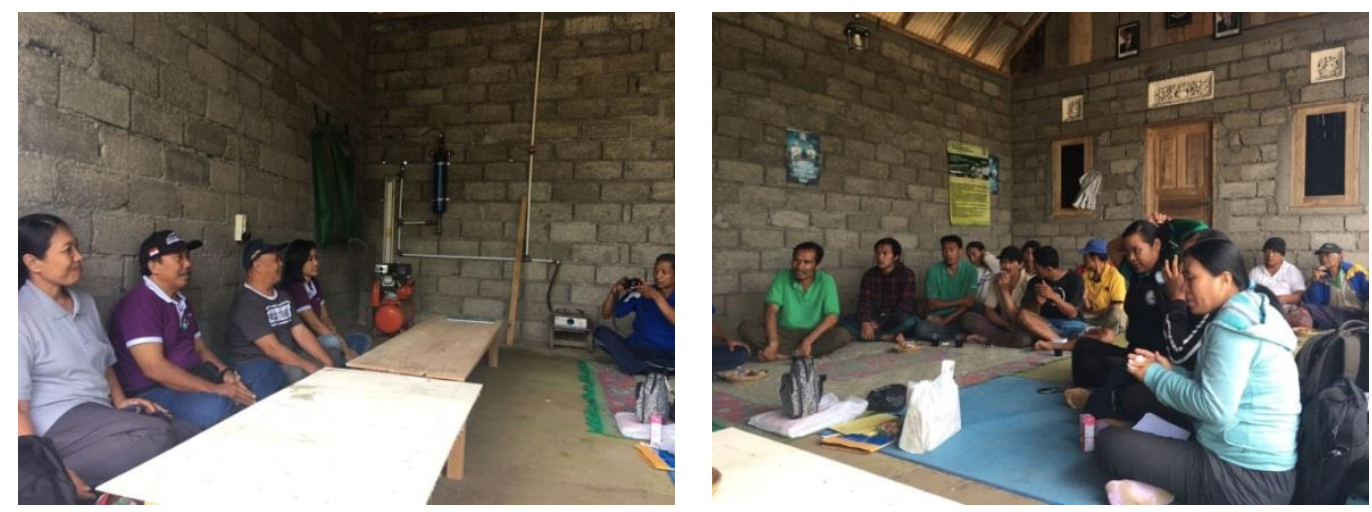

Gambar 3.1 Tim Pelaksana Pengabdi UNUD memberikan penyuluhan kepada kelompok ternak Mekar Sari dan peternak mandiri di dusun Sekarmukti, Desa Belok/Sidan 
Pelayanan kesehatan difokuskan terhadap pencegahan melalui pemberian obat cacing, spraying (Gambar 3.2). Tindakan spraying dilakukan terhadap semua ternak sapi di kelompok Mekar Sari. Hal ini dimaksudkan untuk mencegah meningkatnya populasi ektoparasit. Pemberian obat cacing ditujukan pada sapi pejantan, bibit dan betina yang dilaporkan tidak sedang bunting. Kedua kegiatan ini sejalan dan mendukung program rutin yang dilakukan oleh Dinas terkait.
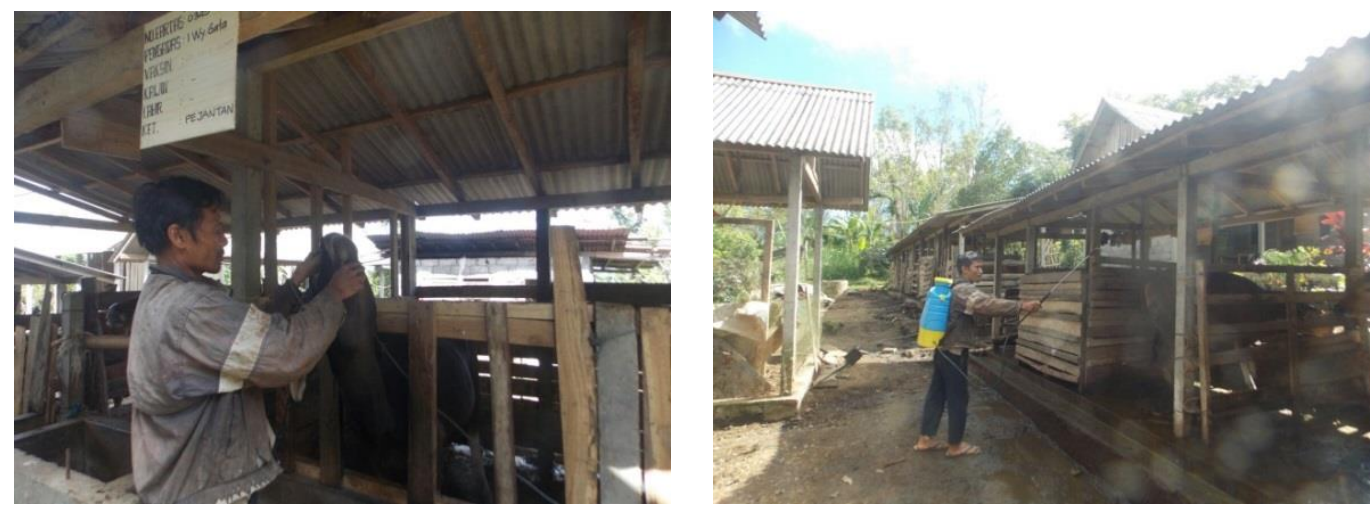

Gambar 3.2 Ketua Kelompok Ternak sapi Bapak Wyn. Gata memberikan obat cacing dan melakukan spraying pada ternak sapi

Pemberi vitamin (Gambar 3.2 A) bertujuan untuk memperbaiki dan meningkatkan kondisi tubuh ternak sapi. Vitamin B Complek yang diberikan dapat meningkatkan nafsu makan, mengoptimalkan pencernaan dan metabolisme tubuh ternak. Vitamin diberikan pada hampir semua ternak sapi, baik yang dilaporkan sehat maupun sakit. Pengobatan hanya diberikan kepada ternak sapi yang dilaporkan mengalami keluhan sakit oleh peternak, dan didahului dengan pemeriksaan untuk menentukan pengobatan yang diberikan (Gambar 3.2 B).
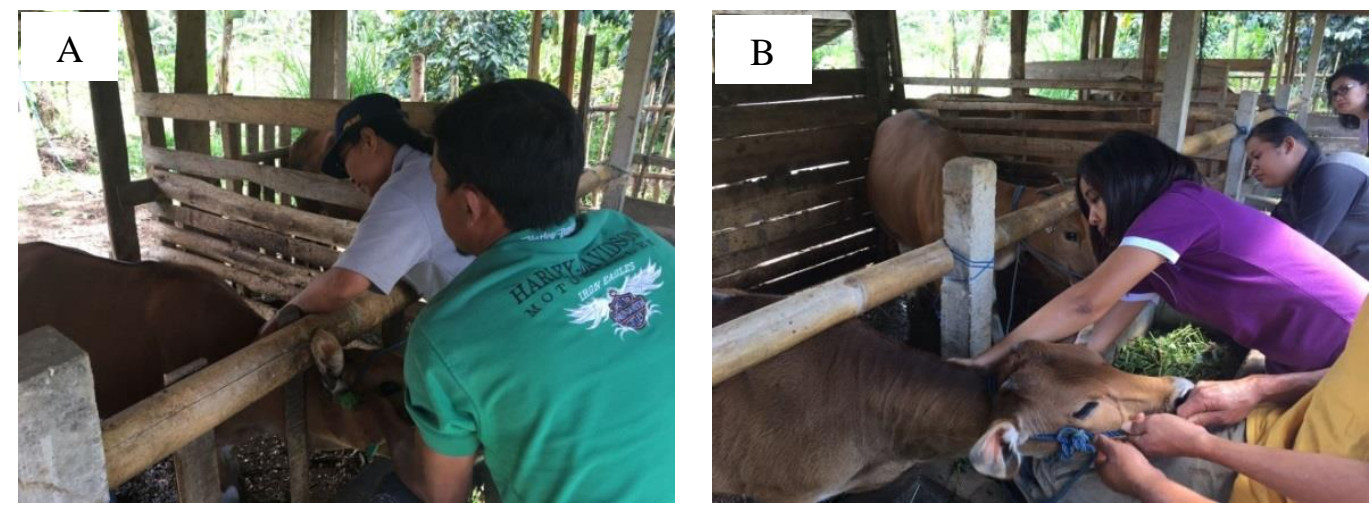

Gambar 3.2 Tim Pengabdi memberikan (A) vitamin; (B) terapi kasus diare pada sapi bali bibit

Selain memberikan penyuluhan dan pelayanan kesehatan, tim pengabdi juga diminta untuk melakukan pemeriksaan kebuntingan terhadap satu ekor ternaknya yang dilaporkan mengalami masalah reproduksi (Gambar $4 \mathrm{~A}$ ). 

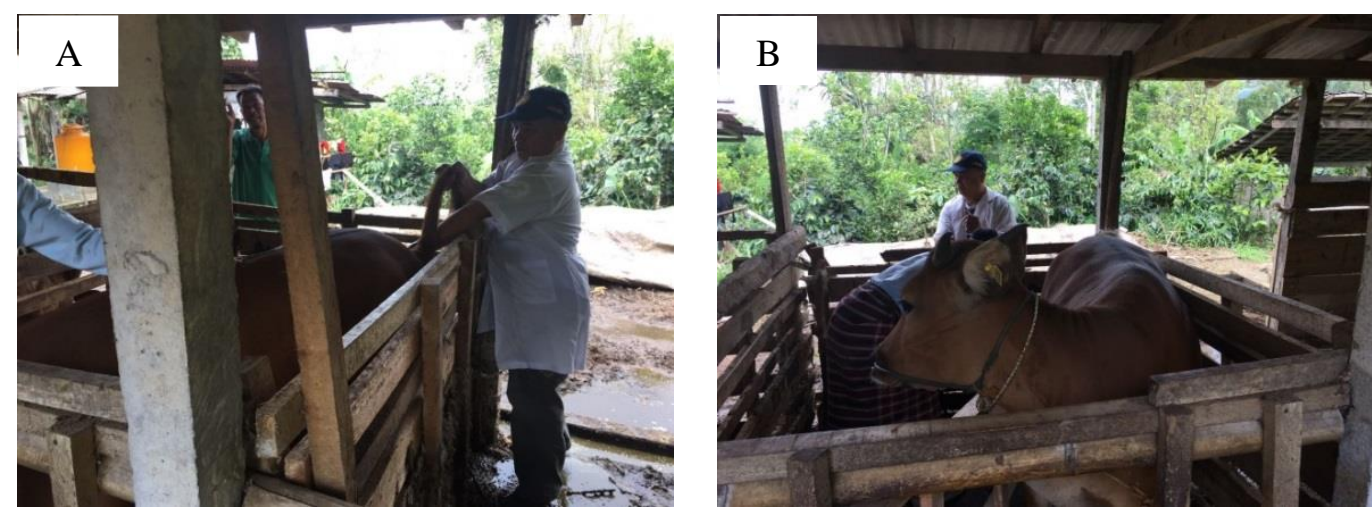

Gambar 3. 4. Tim pengabdi melakukan (A) pemeriksaan kebuntingan untuk menentukan masalah reproduksi berdasarkan laporan salah seorang peternak; (B) persiapan pengambilan feses sapi untuk diperiksa di Lab Parasitologi FKH UNUD

Untuk keperluan evaluasi hasil pengabdian yang telah dilakukan, tim pengabdi mengambil sampel feses dari beberapa ekor sapi di kelompok ternak Mekar Sari (Gambar 3.4 B). Hasil pemeriksaan dengan metode natif menunjukkan bahwa beberapa ternak sapi terinfeksi nematode tipe strongyle ascaris toxocara dan trematoda.

Peternak sapi mengharapkan bahwa kegiatan pelayanan kesehatan seperti yang telah dilakukan oleh tim pengabdian kami, diprogram secara rutin dan berkesinambungan sehingga produktivitas ternak mereka dapat meningkat. Kegiatan ini juga disarankan dilakukan di dusun-dusun lain dari Desa Belok/Sidan.

\section{SIMPULAN DAN SARAN}

\subsection{Simpulan}

Berdasarkan hasil kegiatan pelayanan kesehatan ternak sapi yang telah dilakukan di Desa Belok/Sidan, Kabupaten Badung dapat disimpulkan bahwa masyarakat peternak sapi memberikan respon sangat baik terhadap kegiatan yang telah dilakukan. Jumlah sapi bali yang dapat diberikan pelayanan sebanyak 190 ekor

\subsection{Saran}

Kegiatan pelayanan kesehatan ternak sapi di Desa Belok/Sidan, Kecamatan Petang Kabupaten badung dilakukan secara rutin, berkelanjutan, dan cakupan wilayah lebih luas.

\section{UCAPAN TERIMAKASIH}

Penulis mengucapkan terimakasih kepada Lembaga Penelitian dan Pengabdian Kepada Masyarakat Universitas Udayana atas dana DIPA PNBP yang diberikan, dengan Surat Perjanjian Penugasan Pelaksanaan Hibah Pengabdian kepada Masyarakat Udayana Mengabdi Nomor: 67412/UN14.4A/PM/2017, tanggal 12 Juli 2017. Ucapan terimakasih juga ditujukan kepada Tenaga Pendamping Kelompok Ternak Mekar Sari dan Petugas PPL Desa Belok/Sidan, Kecamatan Petang, Kabupaten Badung yang telah terlibat secara aktif dalam pelaksanaan pengabdian ini. 


\section{DAFTAR PUSTAKA}

Adjir, RMA. 2014. Strategi Alternatif Pengendalian Penyakit Reproduksi Menular Untuk meningkatkan Efisiensi Reproduksi Sapi Potong. Wartazoa. 14(3): 125-132

Aldridge, BM., FB., Garry, R. Adams. 1993. Neonatal septicaemia in calves. JAVMA. 203(9): 1324 - 1329. Bandini, Y. 2004. Sapi Bali. Penebar Swadaya. Jakarta.

Guntoro, S. 2002. Membudidayakan Sapi Bali. Kanisius, Yogyakarta.

Margerison, J., N. Downey. 2005. Guidellines for Optimal Dairy Hefer Rearing and Herd Perfomance. In Calf and Heifer Rearing. Principles of Rearing the Modern Dairy Heifer from Calf to Calving. Edited by PC.Garnsworthy Nottingham University Press.

Malik, Subhash, Amit Kumar Verma, Amit Kumar, M.K. Gupta, S.D. Sharma. 2012. Incidence of Calf Diarrhea In Cattle and Bufallow Calves in Uttar Pradesh, India. Asian Jornal of Animal and Veterinary Advadences. 7 (10) : 1049-1054

Nagwa, SA., SM. Dorgham, EA. Khairy, MS. Zaki. 2013. Calf Scours : De $\square$ nition and causes. Life Science Journal. Vol 10 (1). http//wwwlifesciencesite.com

Priadi, A., L. Natalia. 2005. Bakteri Penyebab Diare Pada Sapi dan Kerbau di Indonesia. Seminar Nasional Teknologi Peternakan dan Veteriner 2005: 38-44

Supar, Kusmiyati, M.B. Poerwadikarta. 1989. Aplikasi vaksin enterotoksigenik Escherichia coli (ETEC)K99, F 41 Polivalen pada induk sapi perah bunting dalam upaya pengendalian kolibasilosis dan kematian pedet neonatal. JITV 3(1): $27-33$.

Williamson, L. 2003. Large animal digestive system: Young ruminant diarrhea. 